\title{
Kamu Alacaklarının Korunma Yöntemleri ve Bir Değerlendirme
}

Hakan AY

Tülay BARAN

hakan.ay@deu.edu.tr

barantulay@yahoo.in

\section{The Protection Methods of Public Claims and an Appreciation}

\begin{abstract}
As a requirement of social state concept (discipline/approach) an increase in public services leads to an increase in public spending. Public revenues should be increased parallel to the increase in public expenditures. This situation increases the importance of the public claims. In Turkish tax system, public claims are monitored within the framework of the Law No. 6183 on the Procedure for the Collection of Public Claims (receivables). The protection of public claims is also very important as well as the collection of public claims. In this study, the important ones of the protection methods for the collection of public claims are described.
\end{abstract}

Keywords

: Public Claims, Tax Collection, Protection method of Public Claims.

JEL Classification Codes : $\mathrm{H} 70, \mathrm{H} 71$.

\section{Özet}

Sosyal devlet anlayışının gereği olarak kamu hizmetlerinin artması, kamu harcamalarının da artmasına neden olmaktadır. Kamu harcamalarının artmasına paralel olarak kamu gelirlerinin de arttırılması gerekmektedir. Bu durum kamu alacaklarının önemini arttırmaktadır. Türk vergi siteminde kamu alacakları 6183 Sayılı Amme Alacaklarının Tahsil Usulü Hakkında Kanun çerçevesinde takip edilmektedir. Kamu alacaklarının tahsilinin yanı sıra kamu alacaklarının korunması da çok önemlidir. $\mathrm{Bu}$ çalışmada, kamu alacaklarının tahsilini koruma yöntemlerinden önemli olanları açıklanmıştır. 
Hakan AY \& Tülay BARAN 


\section{Giriş}

Devlet anlayışının dönemler itibariyle değişim içerisinde olması sonucunda, kamu yararını sağlamak amacıyla devletin sorumluluğu artmakta, üstün ve ayrıcalıklı usuller kullanılarak kamu hizmeti faaliyetleri yürütülmektedir. Kamu hizmeti kavramının anayasada veya kanunlarda herhangi bir tanımı olmamakla birlikte öğretide bu kavram; tatmininde kamu yararı olan toplumsal bir gereksinimi karşılayan faaliyet olarak kullanılmaktadır (Günday, 2005: 161). Bu bağlamda kamu hizmetlerinin karşılanması ve yürütülmesi için devlet, anayasadan aldığı yetkiyle mali yükümlülükler koymaktadır. Devlet açısından kamu alacağı sayılan, idare hukuku anlamında bir idari işlem konusu olan bu mali yükümlülükler, devletin alacak ya da borç ilişkisi sonucu idari işlemlerle sağladığı kamu gelirleridir (Öncel, Kumrulu, Çağan, 2008: 159). Kamu alacağ 1 kavramı, kamu alacaklarının takip ve tahsilini düzenlemek için yürürlüğe konulan Amme Alacaklarının Tahsil Usulü Hakkında Kanun (AATUHK)'un 1. maddesinde açıkça belirtilmiştir. Buna göre: "devlete, vilayet hususi idarelerine ve belediyelere ait vergi, resim, harç, ceza tahkik ve takiplerine ait muhakeme masrafı, vergi cezası, para cezası gibi asli, gecikme zammı faiz gibi fer'i amme alacakları ve aynı idarelerin haksız fiil ve haksız iktisaptan doğanlar dışında kalan ve amme hizmeti tatbikatından mütevellit olan diğer alacakları ile bunların takip masrafları hakkında bu kanun hükümleri tatbik olunur". Türk Ceza Kanununun para cezalarının tahsil şekli ve hapse tahvili hakkındaki hükümleri mahfuzdur" hükmü ile kamu alacağı kavramının sınırları çizilmiştir. Maddede belirtilenler haricinde tam olarak kamu alacağı niteliği taşımayan ancak tahsili açısından bu kanun hükümlerine atıfta bulunulan alacaklar da mevcuttur.

Toplumun ihtiyaçlarını yerine getirmeye çalışan devlet, sunmakla yükümlü olduğu kamu hizmetleri için yaptığı harcamaları karşılamak amacıyla özel kesimden kamu kesimine değerler aktarmak zorundadır. $\mathrm{Bu}$ değerlerin devletin alacaklı sıfatını kazanmasıyla birlikte kamu borçluları tarafından vadesinde ödenmeleri esastır (Karakoç, 2001: 121). Tarh ve tahakkuk eden vergiler kendi vergi kanunlarında gösterilen süreler içinde (vadelerinde) ödenmektedir. Tarh edilen vergilerin vadesinde ödenmesi gerekmektedir. Kanunlarda belirtilen vadelerde ödenmeyen vergi, resim ve harçlar için cebren tahsil metodları uygulanmaktadır. Cebren tahsil şekillerinde mükellef hakkında; mükellefin vergi idaresinde teminatı bulunması durumunda, teminatın paraya dönüştürülmesi veya şahsi kefalet söz konusu ise, kefilin takibi, borca yetecek miktarda menkul ve gayrimenkul malların haczedilip, paraya dönüştürülmesi ve gerekli koşulların da oluşması durumunda mükellefin iflasının dahi talep edilmesi sonucuna dek bir dizi işlemler yapılabilmektedir. Bu bir dizi işlemlerin yapılabilmesi için de, öncelikle, kamu alacağ Kamu alacaklarının tahsili, alacağın ödenmesi ve alacağın zorla tahsili olarak iki şekilde gerçekleşebilmektedir. Alacağın zamanında ve kanunlara uygun biçimde ödenmesiyle kamu borçlusunun yükümlülüğ̈̈ sona erer. Ancak borcun zamanında ve usulünün 
gerektirdiği şekilde ödenmemesi durumunda borçlu hakkında AATUHK'nın hükümlerine göre cebren tahsil yollarına başvurulacaktır. Kamu alacağının ileride tahsil edilememezlik gibi bir durumla karşı karşıya kalınması halinde alacağı güvence altına almış olmak adına AATUHK'nın 9. ile 36. maddeleri arasında geniş kapsamlı düzenlemeler yapılmıştır. Tahakkuk etmiş ve tahakkuk etmemiş kamu alacaklarının korunması şeklinde kullanılan bu yöntemler şöyledir:

Tahakkuk Etmemiş Kamu Alacaklarının Korunması Yöntemleri

- Teminat İsteme-Şahsi kefalet,

- İhtiyati haciz,

- İhtiyati tahakkuk.

Tahakkuk Etmiş Kamu Alacaklarının Korunması Yöntemleri

- Rüçhan hakk1,

- Amme alacaklarını kesip ödemek mecburiyetinde olanlar,

- Tahsil edilen amme alacaklarından yapılacak reddiyat sebebiyle mahsuplar,

- Amme alacağı ödenmeden yapılamayacak işlemler,

- İptal davası açılması,

- İvazsız tasarrufların hükümsüzlüğü, Bağgşlama sayılan tasarruflar,

- Hükümsüz sayılan diğer tasarruflar,

- Amme alacağının tahsiline imkân bırakmamak maksadıyla yapılan tasarruflar,

- Tasfiye halinde vazifeliler, Ortaklığın feshini isteme,

- Limited şirketlerin amme borçları,

- Kanuni Temsilcilerin Sorumluluğu,

- Birleşme, devir, bölünme ve şekil değiştirme.

$\mathrm{Bu}$ çalışmada kamu alacaklarının korunması yollarının tümünü ele almaktan ziyade bu kapsamda önemli görülen ve problemli durumlarla karşılaşılan teminat, ihtiyati haciz, ihtiyati tahakkuk ve diğer koruma hükümlerinden rüçhan hakkı, iptal davası, limited şirketlerin kamu borçları ve kanuni temsilcilerin sorumluluğu incelenecektir. 


\section{Kamu Alacaklarının Korunması Yöntemleri}

\subsection{Teminat İsteme}

Teminat kelime olarak güvence anlamına gelmektedir. AATUHK'nın 9. maddesinde düzenlenen teminat ise, kamu alacağının korunması bakımından ilk önlem olmakla birlikte kamu borçlusunun malvarlığına dâhil kıymetleri idarenin isteği üzerine, fakat kendi belirlemesi ile borcuna karşılık göstermek suretiyle kamu alacağının güvence altına alınması amacına yönelik bir uygulamadır. Maddenin ilk fikrasında teminat istenebilmesi için gerekli durumlar belirtilmiştir. Bunlar; Vergi Usul Kanununun (VUK) 344. maddesinde vergi ziya1 cezası kesilmesini gerektiren haller ile aynı kanunun 359 . maddesinde düzenlenen kaçakçılık suçunu oluşturan hallerden birinin mevcut olması ve bu hallere temas eden kamu alacağının salınması için gerekli işlemlere başlanmış olunmasıdır. $\mathrm{Bu}$ takdirde vergi incelemesine yetkili memurlarca yapılan ilk hesaplara göre belirtilen miktar üzerinden teminat istenecektir (Özbalc1, 2012: 162). Teminatın istenmesi için başlamış olan inceleme sonucunda tarhiyatın tamamlanmasının beklenmesi gerekli değildir, ancak rapor tamamlanarak vergi ve ceza ihbarnamelerinin tebliğ edilmesinden sonra teminat istenemeyecektir (K1zılot, 2010: 15). Teminat istenmesini gerektiren hallerin varlığı durumunda hem vergi aslına ilişkin ortaya çıkacak matrah farkını hem de vergi cezasını karşılayacak şekilde belirlenen miktar üzerinden mükelleften teminat istenecektir (Serim, 2007: 19). Maddenin ikinci fikrasında ise, kamu borçlusunun Türkiye'de ikametgâhının bulunmaması ve durumunun kamu alacağının tahsilinin tehlikede olduğunu göstermesi halinde teminat istenebileceği belirtilmiştir. $\mathrm{Bu}$ iki koşulun birlikte gerçekleşmesi gerekmektedir. Kamu borçlusunun durumunun kamu alacağının tahsilinin tehlikede olduğunu gösterip göstermediği olayın kendi koşulları içerisinde belirlenecektir. Örneğin; kamu borçlusunun Türkiye'de bulunan tüm malvarlığını nakde çevirme girişimlerinde bulunduğunun tespiti, yine borçlunun işlerini tasfiye etmesi ve seyahat hazırlıkları yapması gibi durumlarda maddenin uygulanabilirliği meydana gelecektir (Candan, 2007: 82). Maddenin birinci fikrasında "istenir" şeklinde biten kesinlik belirten hükme göre uygulanan teminat isteme işleminde, teminatın istenme nedenini tespit etmek tahsil dairesinin yetkisinde değildir. Vergi inceleme elemanı takdirini teminat istenmesi yönünde kullandığında tahsil dairesi bağlı yetki ile hareket etmek durumundadır. Ancak ikinci fikradaki "isteyebilir" şeklindeki biten hükme göre teminatın istenme nedenini tespit etmek ve teminatın gerekliliği takdiri tahsil dairesinin görevidir (Baysal, 2009: 1167). 281 nolu Tahsilât Genel Tebliği ile belirsizlik ortadan kaldırılmaya çalışılmışsa da uygulamada teminatın istenmesi konusunda yetki sakatlığ 1 gibi farklı durumlarla karşılaşılmaktadır. $\mathrm{Bu}$ sebepten madde metninin teminat istenmesine karar verme zorunluluğu ve yetki kullanımının ayrıntılı ve net olarak tekrar düzenlenmesi gereklidir.

Teminatın ne şekilde isteneceği ve süresi konusunda kanunda bir açıklama olmamakla beraber uygulamada teminat yazıyla istenmektedir. Teminat isteme yazısı kesin 
ve yürütülmesi gereken idari bir işlem olmasından dolayı idari davaya konu edilebilecektir (Candan, 2007: 83). AATUHK'nın 8. maddesinde aksine bir hüküm bulunmadıkça yazılı sürelerin hesaplanmasında VUK hükümlerinin uygulanacağı belirtilmiştir dolayısıyla teminat isteme için verilecek süre 15 gün olarak hesaplanacaktır. Nelerin teminat olarak gösterileceği ise AATUHK'nın 10. maddesinde hüküm altına alınmıştır. Buna göre; para, bankalar ve özel finans kurumları tarafindan verilen süresiz teminat mektupları, Hazine Müsteşarlığınca ihraç edilen devlet iç borçlanma senetleri veya bu senetler yerine düzenlenen belgeler hükümetçe belli edilecek milli esham ve tahvilat ilgililer veya ilgililer lehine üçüncü kişiler tarafindan gösterilen ve alacaklı kamu idaresince haciz varakasına istinaden haczedilen menkul ve gayrimenkul mallar teminat olarak kabul edilecektir. Maddede belirtilen türden teminatı sağlayamayanlar ise AATUHK'nın 11. maddesinde açıklanan, muteber bir şahsı noter tasdikli sözleşme ile müteselsil kefil ve müşterek müteselsil borçlu göstererek şahsi kefalet müessesesinden yararlanabilecektir. Kefili kabul edip etmemekte tahsil dairesinin yetkisi mevcuttur, ancak kamu borçlusunun teminat olarak gösterilebilecek malı olduğunun belirlenmesi durumunda tahsil dairesinin şahsi kefili kabul etmemesi gerekir (Çelik, 2000: 49). Gelir Vergisi Kanununda gayrimenkul olarak tescil edilen markanın, AATUHK'da ve İcra İflas Kanunu'nda (İIK) hem ihtiyati haczi hem de kesin haczi ve satışı mümkün bulunmaktadır. Hatta İIK'da teminat olarak bile gösterilebilen tescilli bir marka AATUHK'nın teminat müessesesi kapsamına da alınması gerekmektedir (Serim, 2008: 559-561). Teminat olarak gösterilen değerler zamanla değer kaybına uğrayabilir veya kamu borcunda bir artış meydana gelir ise eksilen teminatın tamamlanması kamu borçlusundan istenecektir. İstek yerine getirilmezse alacağın teminatsız kalan kısmı için ihtiyati haciz uygulanır. Diğer taraftan kamu borçlusu daha önce vermiş olduğu teminatı kısmen veya tamamen aynı değerde başka kıymetlerle değiştirebilir, ancak değiştirme sırasında gecikme faizi gibi nedenlerle borç artmışsa yeni tutar esas alınacaktır (Özbalcı, 2012: 181). Teminatın iadesi hakkında AATUHK'da bir hüküm bulunmamakla beraber teminatın alınış nedeni ortadan kalktığı takdirde iade edilmesi gerekir. Teminatın alınmasını gerektiren alacağın ödenmesinden sonra borçlunun başka borçlarının da bulunduğunu ileri sürerek teminatı elinde tutmaya devam edemez. Teminatın geri verilmesi yolunda yapılan istekler reddedilirse genel dava açma süresi içinde idari davaya konu edilebilir(Candan, 2007: 87).

AATUHK'nın 12. maddesinde ise bar, otel, han, pansiyon, çalgılı yerler, sinemalar, oyun ve dans yerleri, birahane, meyhane, genelevler içerisinde bulunan eşya ve malzemenin, İIK'nın 270. ve 271. maddeleri hükümleri mahfuz kalmak şartıyla bu müesseselerin işletilmesinden doğan kamu borçlarına karşı teminat hükmünde olduğu belirtilmiştir. Üçüncü kişilerin bu yerlerdeki mallar üzerindeki istihkak iddiaları ise alacaklı kamu idaresinin teminat hakkını ihlal etmeyecektir (Barlas, 2011: 153). Teminat istenmesinin sonucu, kamu borçlusu veya mükellef ve sorumluların tahakkuk eden ve edecek olan bütün borçları için ihtiyati haciz uygulanması gerekmesidir. Çünkü AATUHK'nın 13. ve 17. maddesine göre teminat istenmesini gerektiren haller hem ihtiyati haciz hem de ihtiyati tahakkuk nedeni sayılmıştır (İstanbul Vergi Dairesi Başkanlığı, 2006: 
46). İkinci bir sonucu da teminat gösterilmesi halinde cebren tahsil, şartların oluşması durumunda teminatın paraya çevrilmesi veya kefilin takibi yoluyla yapılacaktır. $\mathrm{Bu}$ yöntemin kullanılma sırası hakkında AATUHK'da bir hüküm belirtilmemiş olsa da tahsilin seri bir şekilde ve en az masrafla yapılabilmesi sağlanacaktır.

\section{2. İhtiyati Haciz}

AATUHK'nın 13. maddesinde düzenlenen, kamu alacağının korunması bakımından en etkili takip başlangıcı olarak sayılan ihtiyati haciz, ileride tahakkuk edecek olan veya henüz vadesi gelmemiş bulunan ya da vadesi geçtiği halde ödeme emri tebliğ edilmemiş bulunan kamu alacağının tahsil güvenliğini sağlamak için yapılan hacizdir (Tombaloğlu, 2011: 107). İhtiyati haciz idari bir tasarruf niteliğinde olan icrai bir kararla ve idarenin re'sen hareket yetkisi çerçevesinde uygulanmaktadır. Kamu alacağının güvencesi olarak verilen değerlerin idare tarafindan saptanması, ihtiyati hacze cebri teminat niteliği vermektedir. Kanunun kamu borçlusu tarafından AATUHK'nın 10. maddesinin beşinci fikrasındaki yazılı menkul mallar hariç olmak üzere teminat gösterildiğinde ihtiyati haczin kaldırılmasını öngörmesi ve ihtiyaten haczolunan malların değerleri depo edilmek ya da kamu alacaklısının kabul edeceği bir kişiyi müteselsil kefil gösterilmek şartıyla borçluya bırakılmasını kabul etmesi ihtiyati hacizin cebri teminat niteliğinde olduğu görüşünü desteklemektedir (Dönmez, 2007: 242). Cebri icra takibatının asli koşulu, ödeme emrinin düzenlenip, mükellefe veya yetkili kişiye tebliğ edilmesidir. Ödeme emri tebliğ edilmeden, cebri icra işlemlerin yapılması söz konusu olmayacaktır (Ay ve Alpaslan, 2011: 166). Ödeme emri tebliğ olunduktan sonra, fakat yedi günlük sürenin dolmasından önce de ihtiyati haciz kararı alınıp uygulanabilir. İhtiyati haciz, ancak ihtiyati tahakkuk yapılmış olması koşuluyla henüz tahakkuk etmemiş kamu alacakları ile kesin haciz uygulaması aşamasına gelmemiş tahsili kabil kamu alacakları için mümkündür. (Candan, 2007: 94).

İhtiyati haciz uygulanabilmesi için;

- Teminat istemeyi gerektiren durumların varllğı,

- Kamu borçlusunun belirli bir ikametgâhının olmaması,

- Kamu borçlusunun kaçmış olması ya da kaçma, mallarını kaçırma ve hileli yollara sapma olasılığının bulunması,

- Borçludan teminat göstermesi istendiği halde belirli sürede teminat ya da kefil göstermemiş olması ya da gösterdiği kefilin kabul edilmemesi,

- Mal bildirimine çağırılan kamu borçlusunun mal bildiriminde bulunmaması ya da eksik bildirimde bulunması, 
- Hüküm verilmiş olsun veya olmasın para cezasını gerektiren bir fiil dolayısıyla kamu davası açılmış olması,

- İptali istenen işlem ve tasarrufun konusunu teşkil eden mallar, bu mallar elden çıkarılmışsa elden çıkaranın diğer malları hakkında uygulanmak üzere, AATUHK'nın 27., 29. ve 30. maddelerin (bazı karşılıksız tasarruflarla, hükümsüz sayılan ve vergi alacağının tahsiline imkan bırakmamak amacı ile yapılan tasarruflar) tatbikini icabettiren hallerin olması gerekmektedir.

$\mathrm{Bu}$ şartların mevcudiyeti halinde alacaklı kamu idaresinin mahalli en büyük memurunun yani illerde valiler, ilçelerde kaymakamların kararı ile ihtiyati haciz herhangi bir süreyle sınırlı olmaksızın derhal uygulanacaktır (Mutluer, 2006: 452). İhtiyati haciz kararı kamu borçlusu sıfatını taşıyan vergi mükellefi, vergi sorumlusunun yanı sıra kanuni temsilciler, mirasçılar, kefiller, yabancı şahıs ve kurum temsilcileri ve şahsi şirket ortakları hakkında da uygulanacaktır. Danıştay vergi kaçırmayı azmettirenler ile vergi kaçakçılığına karışanlar hakkında da ihtiyati haciz kararı alınabileceğini kabul etmektedir (Yerlikaya, 2011: 11). İhtiyati hacze karşı dava açma süresi haczin tatbiki, gıyapta yapılan hacizlerde haczin tebliği tarihinden itibaren 7 gün olup, dava alacaklı tahsil dairesine ait vergi davası işlerine bakan vergi mahkemesinde açlacaktır. İhtiyati haciz kararlarına ve uygulanmalarına karşı açılacak olan davalarda usul yönünden ihtiyati haciz uygulanmasının usulüne uygun olup olmadığı hususu, esas yönünden ise sadece ihtiyati haciz nedenlerinin bulunmadığı öne sürülebilir(Özbalcı, 2012: 239-241). Vergi, resim, harç ve benzeri mali yükümlerle bunların zam ve cezaları dışındaki kamu alacaklarını güvence altına almak amaciyla alınan ihtiyati haciz kararlarının ise idare mahkemelerinde idari davaya konu edilmeleri olanaklıdır (Candan, 2007: 108).

Gelir İdaresi Başkanlığı tarafından Vergi Dairesi Otomasyon Projesi (VEDOP) kapsamında elektronik haciz (e-haciz) uygulaması başlatılmıştır. Vergi kaçağını önlemeye yönelik olarak geliştirilen sistemle vergi borcunu ödemeyenlerin banka hesaplarına elektronik ortamda el koyulması hedeflenmştir (Alptürk, 2008). Uygulamada vergi daireleri hakkında ihtiyati haciz, ihtiyati tahakkuk önerilen mükellefler ile ilgili malvarlığ araştırmaları yapılması sırasında henüz kesinleşmeyen borçlarla ilgili mükelleflerin banka hesaplarına e-haciz koyabilmektedir. Danıştay'ın vergi incelemesi bittikten sonra ihtiyati haciz ve ihtiyati tahakkuk önerilemeyeceğine ilişkin vermiş olduğu birçok karar vardır. $\mathrm{Bu}$ konu hakkında uygulamada yapılan hata; vergi incelemesi son bulduktan sonra mükellef hakkında idarenin, ihtiyati haciz ve tahakkuk kararı alıp bu kararı hemen uygulamak için bankalara yazı yazarak haciz işlemlerini başlatmasıdır. Ancak e-haciz veya banka mevduat hacizleri ihtiyati tahakkuk ve ihtiyati haciz kararlarının kesinleşmesine bağlıdır (Ay, Alpaslan, Kaya, 2011: 36). AATUHK'da kamu borçlusunun her türlü mal, hak ve alacaklarına uygulanabileceği belirtilmekle beraber, sadece kamu borçlusunun bankalar nezdinde bulunan ve ileride tahakkuk edecek miktarlar üzerinde ihtiyati haczin mümkün olmadığı belirtilmiştir. 
İhtiyati haciz, kamu borçlusunun ihtiyati hacze konu malları üzerindeki tasarruf yetkisini kaldırır ve borçlu, normal hacizde olduğu gibi kamu alacaklısının muvafakatını almaksızın ihtiyaten haczedilen mallar üzerinde tasarruf edemez. Kamu alacaklısı ise kamu alacağının vadesi dolmadan önce haczedilen malları satış talebinde bulunma yetkisine sahip olamamaktadır (Dönmez, 2007: 243). Anayasa mahkemesinin kararıyla İdari Yargılama Usulü Kanununun (IYUK) 28/1 madde hükmünün iptal edilmesinden dolay1, haciz ve ihtiyati haciz ile ilgili olarak mahkemelerce verilen iptal veya yürütmeyi durdurma kararları üzerine nihai kararın kesinleşmesini beklemeksizin vergi dairelerince kararın gereklerine göre işlem tesis edilmesi gerekmektedir. İhtiyati haciz uygulamasından beklenen faydanın elde edilebilmesi için, ihtiyati haciz kararının ivedilikle uygulanması zorunludur. Dolayısıyla ihtiyati haciz kararlarına ilişkin işlemlerin elden takip edilerek gecikmeye yer verilmeden tamamlanması ve haciz kararlarının gerek hazırlanması ve gerekse uygulanması aşamalarında gizlilik içerisinde hareket edilerek borçlunun mallarını kaçırmasına engel olunması gerektiği tabidir (Aygün, 2010: 26). AATUHK ihtiyati haczin genel olarak haczin uygulanmasına ilişkin hükümlere göre tatbik edilmesini öngörmüştür. $\mathrm{Bu}$ konuda hacze konu olabilecek varlıklar ve istihkak iddiası konuları kesin haciz uygulamasındaki gibidir. Ancak rüçhan hakkı konusunda doktrinde farklı görüşler mevcuttur. Kimi yazar ihtiyati hacze bağlanmış kamu alacaklarının rüçhan hakkından faydalanabileceğini savunmaktayken, kimileri ise ihtiyati hacze konu olmuş kamu alacağı ancak kesinleşmiş ve cebren tahsil edilebilir hale gelmişse kamu alacağının rüçhan hakkından istifade edeceğini savunmaktadır. Bunlardan rüçhan hakkının ihtiyati haciz müessesesinde uygulama alanının olmadığı görüşü savunulabilir. Hem kanunda böyle bir hüküm bulunmamasının hem de kesinleşip miktar belirlemesinin yapılmadığının ileri sürülmesi bu görüşü destekler niteliktedir (Dönmez, 1998: 53).

Tablo: 1

İhtiyati Haciz İle Kesin Haczin Ayrım Noktaları

\begin{tabular}{|l|l|}
\hline Kesin Haciz & İhtiyati Haciz \\
\hline Ödeme emri çıkartılmış ve tebliğ edilmiş olması gerekir. & $\begin{array}{l}\text { Ödeme emri tebliğ edilmeyen alacaklarda } \\
\text { uygulanır. }\end{array}$ \\
\hline Haczedilen mallar paraya çevrilir. & Haczedilen mallar paraya çevrilemez. \\
\hline Tahakkuk etmiş alacaklar olması gerekir. & $\begin{array}{l}\text { İleride tahakkuk edecek alacaklar için } \\
\text { uygulanabilir. }\end{array}$ \\
\hline Süre belli edilmediğinden dava açma süresi 30 gündür. & Dava açma süresi 7 gündür. \\
\hline $\begin{array}{l}\text { Kesin hacze yetkili makam Vergi Dairesi Başkanı ve tevkil } \\
\text { edeceği memurdur. }\end{array}$ & $\begin{array}{l}\text { İhtiyati hacze yetkili makam Vergi Dairesi } \\
\text { Başkanıdır. }\end{array}$ \\
\hline 6183 Sayılı AATUHK'nın 62. maddesine göre haciz konulur. & $\begin{array}{l}\text { 6183 Sayılı AATUHK'nın 13. maddesine göre } \\
\text { haciz konulur. }\end{array}$ \\
\hline
\end{tabular}

Kaynak: Ihtiyati Tahakkuk ve Ihtiyati Haciz Uygulama Rehberi, İstanbul Vergi Dairesi Başkanlı̆̆ Mükellef Hizmetleri Tahsilat Grup Müdürlüğ̈̈, 2008. 


\section{3. İhtiyati Tahakkuk}

Kamu alacaklarının korunması için hukuk sistemimizin bir başka uygulaması da AATUHK'nın 17.maddesinde düzenlenen ihtiyati tahakkuk müessesesidir. İhtiyati tahakkuk, alacaklı kamu idaresi bakımından alacağın tahsilinin tehlikeye girmesi halinde tahsil aşamasını beklemeyip kamu alacağının güvence altına alınması açısından önemli ve etkin bir müessesedir. Kamu borçlusu açısından ise bu uygulamanın varlığı caydırıcı bir etki göstermektedir (Arslan, 2010: 215) Bilindiği üzere vergi borcunun tahakkuk etmesi için tarh ve tebliğ edilmesi gerekmektedir, ancak ihtiyati tahakkuk, vergilendirme sürecinin belli aşamalardan yani tarh tahakkuk gibi normal tahakkuk yollarından geçmesine gerek olmaksızın idari bir kararla vergi borcunun önceden tahakkuk ettirilmesini sağlayan bir uygulamadır (Kızılot, Şenyüz, Taş, Dönmez, 2007: 287).

Bu müessese;

- AATUHK'nın 9. maddesi gereğince teminat istenmesini gerektiren hallerin olması,

- Borçlunun belli ikametgâhının olmaması,

- Borçlunun kaçmış olması veya kaçma, mallarını kaçırma ve hileli yollara sapma ihtimallerinin bulunması,

- Mal bildirimine çağırılan borçlunun belli müddet içinde mal bildiriminde bulunmamış veya eksik bildirimde bulunmuş olması,

- AATUHK'nın 110. maddesi gereğince kamu alacağının tahsiline engel olan borçlu hakkında takibata girişilmiş olması,

- Teşebbüsün muvazaalı olduğu ve hakikatte başkasına aidiyeti hakkında deliller elde edilmiş olması

gibi durumlarda uygulanacaktır. İhtiyati tahakkuk uygulamasına, bu nedenlerden birinin varlığı halinde gidilmesi zorunlu olup, ihtiyati tahakkuk için mükellefin bağlı bulunduğu vergi dairesinin müdürü tarafından Vergi dairesi başkanlığına veya Defterdarlığa yazılı talepte bulunulur. Takdir yetkisi burada vergi dairesi başkanı veya defterdara aittir ancak karar re'sen alınamamaktadır (Gerçek, 2006: 167).

İhtiyati tahakkuk uygulaması tüm kamu alacakları için uygulanmamaktadır. Mükellefin henüz tahakkuk etmemiş vergi ve benzeri mali yükümlülüklerinden Maliye Bakanlığınca tespit ve ilan edilecek olanlar ile bunlara ilişkin gecikme faizi ve cezalar ihtiyati tahakkuka konu olabilecektir. Vergi, resim ve ceza miktarlarından matrahı belli olanlar, belli edilen tutar üzerinden derhal ihtiyati tahakkuk ettirilecektir. Geçmiş yıllara ve 
içinde bulunulan yılın geçen aylarına ait matrahı henüz belli olmayan ve ihtiyati tahakkuk uygulaması kapsamına giren vergi, resim ve cezalar ise geçici olarak harici karinelere göre takdir yolu ile tespit ettirilen matrahlar üzerinden hesaplanarak, hesaplanan tutar üzerinden derhal tatbik ettirilir. İhtiyati tahakkuk işleminin en önemli sonucu, henüz tahakkuk etmeyen kamu alacakları açısından ödeme zamanları gelmeden ihtiyati hacze olanak vermesidir (Netek, 2012: 62). İhtiyati tahakkuk uygulaması geçici bir tahakkuk niteliğinde olduğu için kesin tahakkukla arasındaki farkın düzeltilmesi gereklidir. Kamu alacağının özel kanununa göre tahakkukundan sonra ihtiyati tahakkukla özel kanununa dayanan tahakkuk arasındaki fark, özel kanununa göre düzeltilir. Bu düzeltmenin yapılabilmesi için verilen beyannamenin verildiği tarihten itibaren en geç iki ay içinde incelenerek kabul edilmiş olması gereklidir (Batun, 2010: 91). Haklarında ihtiyati tahakkuk üzerine ihtiyati haciz uygulananlar ihtiyati tahakkuk sebeplerine ve miktarına ihtiyati hacze itiraz hükümleri çerçevesinde itirazda bulunabilirler. Tek başına ihtiyati tahakkuk işlemine karşı itirazın yolu kanunen kapalı bulunmaktadır. Bir itiraz yapılacaksa ancak ihtiyati tahakkuka dayalı ihtiyati haciz işlemine yapılması ve bunun mükellefe tebliği gerekecektir. İhtiyati tahakkuka dayalı ihtiyati hacizde, normal ihtiyati hacizden farklı olarak, sebeplere olduğu gibi ihtiyati haczin miktarına da itiraz edilebilmektedir. Çünkü burada vergilendirme sürecinden geçilmiş ve ihtiyati hacze konu borcun miktarı bilinmektedir. İhtiyati tahakkuk işlemine dayalı ihtiyati haciz tutanağının mükellefe tebliğinden itibaren ya da mükellefin hazır bulunduğu hallerde ihtiyati haczin uygulanmasından itibaren yedi gün içinde ihtiyati tahakkuk ve ihtiyati haciz işlemini uygulayan ilgili tahsil dairesinin bağlı bulunduğu mahkemeye dava açılabilir (Yerlikaya ve Barlas, 2007: 158).

\subsection{Rüçhan Hakkı}

AATUHK'nın 21. maddesinde “üçüncü şahıslar tarafından haczedilen mallar paraya çevrilmeden önce o mal üzerine kamu alacağı için de haciz konulursa bu alacak da hacze iştirak eder ve satış bedeli aralarında garameten taksim olunur" hükmü ile kamu alacağının tahsili güvence altına alınmak istenmiştir. Burada sözü edilen garamet esasından amaç, aynı derecede kayıtlı alacakların tamamını ödemeye para yetmediği takdirde, satış bedelinden sağlanan paranın, alacaklıların alacakları oranında bir paylaşıma tabi tutulmasıdır (Mutluer, 2006: 454). Hesaplama, satış bedelinin garameten taksime girecek olan alacakların toplamına bölünmek suretiyle bulunan rakamın her alacaklının alacak tutarı ile çarpılması suretiyle yapılır (Candan, 2007: 136). Aynı maddeye göre, genel bütçeye gelir kaydedilen vergi, resim, harç ile vergi cezaları ve bunlara bağlı zam ve faizler için tatbik edilen hacizlerde, ihtiyati haciz sahibi alacaklının 'bu hacze İİK'nın 100. maddesindeki şartlar dairesinde iştirak edeceği ve rehinden önce ihtiyati veya icrai haciz bulunması halinde kamu alacağı dâhil hiçbir haczin rehinden önceki hacze iştirak edemeyeceğini" belirten IİK'nın 268. maddesinin birinci fikrasının son cümlesi hükmünün uygulanmayacağı açıklanarak, üçüncü kişiler tarafından haczedilmiş mallara, maddede belirtilen kamu alacakları için rehinden sonra haciz konulması halinde, rehinden önce 
üçüncü kişiler tarafından konulmuş olan hacizlere iştirak edilmesi imkânı sağlanmıştır. Diğer yandan kamu alacağ 1 için konulan hacze aynı borçludan alacaklı olan üçüncü kişilerin iştirakine izin verilmemiştir (Gerçek, 2010: 159).

Rehinli alacaklar kamu alacakları da dâhil olmak üzere tüm diğer alacaklara göre önceliklidir. Bu hükmün istisnası olarak, gümrük vergisi, gümrük resmi, bina ve arazi vergisi, emlak vergisi, veraset ve intikal vergisi, motorlu taşıtlar vergisi ve bu vergilerin cezaları ile gecikme faizi, gecikme zammı ve tescil faizleri gibi taşınmazın veya eşyanın kökeninden kaynaklanan vergiler ve kamu alacakları o eşya ve gayrimenkulün bedelinden tahsilinde rehinli alacaklardan önce gelmektedir. Katma Değer Vergisi (KDV) ise, KDV Kanununun 55. maddesine göre mükelleflerin fabrika veya üretim yerlerindeki ilk madde yardımcı madde ve yarı mamuller veya mamuller üçüncü şahıslara satılmış veya rehnedilmiş bile olsa KDV ile zam ve cezalarının teminatı hükmünde olup, bedellerinden ilk önce KDV ile zam ve cezalarının tahsil edilmesi gerekmektedir. KDV Kanunundaki özel hükümden dolayı bahsi geçen alacakların eşyaların aynından doğma şartı aranmamaktadır (Ay ve Alpaslan, 2011: 2924).

5479 Sayılı Kanun ile AATUHK'nın 21. maddesinde yapılan değişiklikle, İIK'nın 4949 Sayılı Kanun ile değişik 206. maddesi dikkate alınarak, borçlunun iflası, mirasın reddi ve terekenin resmi tasfiyeye tabi tutulması hallerinde kamu alacakları imtiyazlı alacak olarak tanımlanmış ve bu alacakların İIKK'nın 206. maddesinin üçüncü sırasında, bu sıranın önceliğini alan alacaklar da dâhil olmak üzere tüm imtiyazlı alacaklar ile birlikte işleme tabi tutulacağı hükme bağlanmıştır. Yapılan bu değişikliğe göre borçlunun iflası, mirasın reddi ve terekenin resmi tasfiyeye tabi tutulması hallerinde kamu alacakları imtiyazlı alacak olarak İIK'nın 206. maddesinin üçüncü sırasında yer alacaktır. Üçüncü sırada bu sıranın önceliğini alan bir alacağın bulunması halinde, kamu alacakları da öncelikli alacakla aynı sırada yer alacak ve bu alacaklar tamamen tahsil edilinceye kadar diğer imtiyazlı alacaklara bir pay ayrılmayacaktır. Öncelik hakkı bulunan alacak ile kamu alacağı toplamının bu sıraya tahsis edilen tutardan fazla olması halinde ise tahsis edilen tutarın garameten taksim edileceği tabiidir. Diğer yandan İ̇K'nın 206. maddesine göre üçüncü sırada yer alan alacaklar arasında önceliğe sahip bir alacağın bulunmaması halinde, kamu alacağı ile bu sırada yer alan alacaklar birlikte işleme tabi tutularak garameten taksim suretiyle paylarını alacaklardır. Ayrıca kamu alacağının özel kanunlarında İIK'nın 206. maddesinin üçüncü sırasında imtiyazlı alacak olarak tanımlanan alacaklardan da önceliğinin bulunduğuna ilişkin özel hükümlerin yer alması halinde bu hükümlere göre işlem yapılması gerekmektedir. AATUHK bir usul kanunu olduğundan, 5479 Sayılı Kanunla, 21. maddesinde yapılan değişikliğin, halen tahsil edilmemiş olan kamu alacakları ile ilgili olarak tatbik edilmiş ancak paraya çevrilmemiş veya satış bedeli ilgili dairenin veznesine yatırılmamış hacizlerde, anılan maddenin üçüncü fikrasındaki değişikliğin ise kesinleşmemiş sıra cetvellerinde dikkate alınması gerekmektedir (Gelir İdaresi Başkanlığı, 440 seri no'lu Tahsilât Genel Tebliği, 2007). 


\section{5. İptal Davaları}

AATUHK'nın 24. ve 31. maddeleri arasında düzenlenen kamu alacaklarının korunma yöntemlerinden bir başkası olan iptal davası, borçlunun kamu alacağına zarar veren bazı tasarruflarının hükümsüz hale gelmesini sağlamak için tahsil dairesi tarafından açılan bir dava şeklidir. İptal davası alacaklı kamu idaresi veya alacağın tahsilini üstlenen tahsil dairesi tarafından, asıl borçlu ile iptal konusu işlemi yapan kimseler ve bu kimselerin mirasçıları, kötü niyetli üçüncü kişiler ve asıl borçlu tarafindan kendisine bir ödeme yapılanlar aleyhine açılabilecektir (Gerçek, 2010: 166). İptal davasında görevli ve yetkili mahkeme olarak genel mahkemeler belirlenmiş, ayrıca bu davalara diğer davalardan öncelikli olarak görüşülmesi öngörülmüş bulunduğundan adli tatilde de bakılabileceği hüküm altına alınmıştır. İptal davaları belirli bir tutarla sınırlandırılarak sulh veya asliye hukuk mahkemesinde bakılmaktaydı. Ancak 6100 Sayılı Hukuk Muhakemesi Kanununun 2. maddesinde yapılan değişiklikle değer ve miktara bakılmaksızın asliye hukuk mahkemesinin görev alanına girdiği belirtilmiştir.

Açılan iptal davaları ile amaçlanan, kamu alacağını ödemeyen, malı bulunmayan veya borcuna yetmeyen borçlunun kamu alacağının tahsiline olanak vermemek için borçlu tarafından yapılan tek taraflı muamelelerle, borçlunun maksadını bilen veya bilmesi gereken kimselerle yaptığı tasarrufların alacak ve eklentileriyle sınırlı olarak hükümsüzlüğünü sağlayarak dava konusu malı haciz ve satışını isteyebilmesi suretiyle kamu alacağının tahsilini temin etmektir. Bu tür davalar kişisel hakka ilişkin olup, dava sabit olursa davacı dava konusu mal üzerinde cebri icra ile hakkını alma yetkisi elde eder. Dava konusu taşınmaz ise davalı üçüncü kişinin üzerindeki kayıtlı taşınmazın haciz ve satışını isteyebilir, ancak tapu kaydının iptali ile borçlu adına tesciline karar verilemez (Tombaloğlu, 2011: 299).

İptal davası açılabilmesi için öncelikle kesinleşmiş ve ödenebilir hale gelmiş bir kamu alacağının bulunması şart olmakla birlikte bu kamu alacağının takibatının sonuçsuz kalması ve kamu alacağının teminata bağlanamamış olması gerekmektedir. Ancak ihtiyaten tahakkuk ettirilerek ihtiyati haciz uygulanan kamu alacakları kesinleşmediğinde iptal davasına konu olamayacaktır. Bununla birlikte alacağın ödenmesi veya zorla tahsil olanağı mevcut olduğu sürece iptal davasının açılmasına gerek yoktur (İstanbul Vergi Dairesi Başkanlığı, 2006: 129). İptal davası açılması, AATUHK'nın 27., 28., 29. ve 30. maddelerinde öngörülen tasarrufların meydana gelme tarihinden itibaren beş yll geçtikten sonra mümkün değildir. Bu sürenin hak düşürücü süre olduğu kabul edilmekte, kanunda süreyi kesen veya durduran sebeplerin olmayışı da bu kabulü teyit etmektedir. Genel hüküm bu olmakla beraber 27. ve 29. maddelerdeki yer alan iki yıllık süreler daha özel olduğundan bu sürelerin dolmuş olması halinde ilgili bulundukları iptal nedenleri açısından beş yıllık sürenin uygulanamayacağı Yargıtay tarafından da ifade edilmektedir (Özbalcı, 2012: 321). İptal davasına konu tasarruf ve muameleleri, ivazsız tasarruflar, bağışlama sayılan tasarruflar, hükümsüz sayılan diğer tasarruflar ve kamu alacağının tahsiline imkân 
bırakmamak amacı ile yapılan tasarruflar olarak gruplandırılabilir. İvazsız tasarrufların hükümsüzlüğü AATUHK'nın 27. maddesinde sayılmış, buna göre kamu borçlusunun hapsen tazyikine rağmen süresi içinde mal beyanında bulunmamış olması, kamu alacağını karşılayacak malı bulunmadığını bildirmesi veya bildirdiği malı kamu alacağını karşılamaya yetmemesi hallerinden birinin mevcudiyeti halinde ivazsız tasarrufları ve bağışlama sayılan tasarrufları hükümsüz sayılacaktır. Ancak hükümsüzlüğün geçerli olabilmesi için bunların yanı sıra hükümsüz sayılacak tasarrufun kamu alacağının ödeme müddetinin başladığ 1 tarihten geriye doğru iki yıl içinde veya ödeme müddetinin başlamasından sonra yapılmış olması da gerekir. Ödeme müddetinin başladığı tarihten geriye doğru iki yıldan önceki zamanda yapılan tasarruflar koşullar mevcut olsa bile hükümsüz sayılamazlar (Candan, 2007: 147-148).

Bağışlama, bağışlayanın tek taraflı irade beyanı ile sonuç doğuran karşılıksız yani ivazsız bir özel hukuk işlemidir. Bağışlama sayılan tasarruflar ise AATUHK'nın 27. maddesinin tatbiki bakımından 28. maddesinde belirtilmiştir. Buna göre; bir ivaz karşılığında olmasına rağmen, kamu borçlusunun üçüncü dereceye kadar(bu derece dâhil) kan hısımlarıyla (oğlu, kızı, annesi, babası, kardeşleri, amcası, dayısı, halası ve teyzesiyle), eşiyle, ikinci dereceye kadar(bu derece dâhil), sıhri(kayın) hısımlarıyla (kayınbabası, kaynanası, kayınbiraderleri ve baldızlarıyla) yapmış olduğu ivazlı tasarrufları, malı satan, malı karşı tarafa teslim etme davranışını, malı satın alandan akdin yapıldığı sıradaki malın piyasa değerine göre pek aşağı bir fiyat kabul ederek yerine getirmesi şeklindeki tasarruflar, kamu borçlusunun kendisine veya üçüncü bir kişinin menfaatine kaydı hayat şartıyla(ömür boyu) irat(gelir) ve intifa(kullanma) hakkı tesis ettiği akitler bağışlama hükmündedir. AATUHK'nın 29. maddesinde ise hükümsüz sayılan diğer tasarruflar düzenlenmiştir. $\mathrm{Bu}$ maddeye göre; kamu borçlusunun kamu borcu dışındaki mevcut bir borcunun alacaklısına ödenmesini teminat altına almak için kamu borcunun doğumundan sonra verdiği rehinler, borcun karşılanması için para veya alışılmış ödeme araçları dışında onların yerine arazi, arsa, ev ve taşıt araçları verilerek yapılan ödemeler ve vadesi gelmemiş kamu borcu dışındaki bir borç için kamu borçlusunun yaptı̆̆ 1 ödemeler hükümsüz sayılmaktadır (Serim, 2010: 53-54). Tasarrufların hükümsüz sayılması için belirtilen ödeme ve mal bildirimi ile hükümsüz sayılabilmenin zaman koşulu 27. maddede belirtilen koşullarla aynıdır. Burada önemli olan konu, hükümsüz sayılan tasarruflar, mutlak surette iptale tabi olduğundan alacaklıyı zarara uğratma kastı aranmaz ve bu tasarrufların iyi ya da kötü niyetle yapılıp yapılmadığının araştırılmasına gerek yoktur (Gerçek, 2010: 170).

AATUHK'nın 30. maddesinde ise kamu alacağının tahsiline imkân bırakmamak amacıyla yapılan tasarruflar belirlenmiştir. Buna göre, malı bulunmayan veya mevcut malı borcuna yetmeyen kamu borçlusunun, kamu alacağının kısmen veya tamamen tahsilini önlemek ve engellemek amacıyla yaptığı tek taraflı tasarruflar mutlak bir şekilde hükümsüzdür. Tek taraflı muamelelerden kasıt, karşı tarafın irade beyanına lüzum kalmaksızın sadece kamu borçlusunca yapılan hukuki tasarruflardır. Ayrıca borçlunun 
kamu alacağını tahsilsiz bırakmak amacını bilen veya bilmesi gereken şahıslarla yapılan bütün hukuki muameleler tarihleri ne olursa olsun hükümsüzdür (İstanbul Vergi Dairesi Başkanlığı, 2006: 138).

İptal davasının açılması taraflar için bir takım sonuçlar yaratmaktadır. Dava kamu alacaklısı lehine sonuçlanırsa, davaya konu olan taşınır veya taşınmaz mal, malın borçlu veya üçüncü kişi üstünde olması farketmeksizin haczedilir ve satışı gerçekleştirilir. Haciz işlemi kamu alacağının parasal karşılığını aşmayacak miktarda yapılır. Çünkü dava açılmasındaki amaç malın mülkiyetine sahip olmak değil borçlu kişinin tasarrufunun geçersizliğini ispatlayıp kamu alacağının karşılığını tahsil etmektir. Dava kamu alacaklısı aleyhine sonuçlanırsa, dava açılırken idare tarafından alınmış olan ihtiyati haciz kararının derhal kaldırılması gerekir. Ancak, dava kamu idaresi lehine sonuçlanırsa, kamu alacağının tahsiline engel olanlar için düzenlenmiş olan AATUHK'nın 110. maddesi gereği bu kişiler altı aydan üç yıla kadar hapis cezası ile cezalandırılır. İdarenin kamu alacağının tahsili konusunda borçluya duyduğu güven sarsılmış olacağından, idare alacağının tahsilini güvence altına almak amacıyla ileride tahakkuk edecek alacakları için ihtiyati tahakkuk uygulayacak ve bu tutar kadar da ihtiyati haciz kararı alacaktır (Serim, 2010: 56-57).

Hükümsüz sayılan tasarruf ve muameleler, alacaklı kamu idareleri tarafindan iptal ettirildikleri takdirde bunlardan faydalanan üçüncü kişiler elde ettikleri şeyleri aynen iade etmek durumundadırlar. Ancak elden çıkarmışlarsa takdir edilecek bedellerini ödemek mecburiyetindedirler. Üçüncü kişiler aynen verdikleri veya bedelini ödedikleri şeylerden dolayı alacaklı kamu idarelerinden herhangi bir talepte bulunamamakla beraber kamu borçlularına müracaat hakları mahfuzdur. İade edilen mal alacaklı kamu idaresi tarafından haczedilerek icrai takibata devam edilir (Özbalc1, 2012: 341).

\subsection{Limited Şirketlerin Kamu Borçları}

Limited şirket Türk Ticaret Kanununun 573. maddesine göre bir veya daha çok gerçek veya tüzel kişi tarafından bir ticaret ünvanı altında kurulan ticaret şirketidir. Sermayesi belirli olup, bu sermaye esas sermaye paylarının toplamından oluşmaktadır. AATUHK'nın 35. maddesi limited şirketlerin kamu borçlarını kamu alacaklarının korunması amacına yönelik olarak düzenlemektedir. Buna göre; Limited şirket ortakları şirketten tamamen veya kısmen tahsil edilemeyen veya tahsil edilemeyeceği anlaşılan kamu alacağından "sermaye hisseleri oranında" doğrudan doğruya sorumlu olurlar. Ortağın şirketteki payını devretmesi halinde, payı devreden ve devralan şahıslar devir öncesine ait olan kamu alacaklarının ödenmesinden, ayrıca kamu alacağının doğduğu ve ödenmesi gerektiği zamanlarda pay sahiplerinin farklı şahıslar olmaları halinde bu şahıslar kamu alacağının ödenmesinden müteselsilen sorumlu tutulacaklardır. 
Kamu alacağının Limited şirket kanuni temsilcileri veya ortaklarından tahsil edilebilmesi için, Limited şirketin hakkında tüm cebren tahsil ve takip yolları uygulanıp, kamu alacağının şirketten tamamen veya kısmen tahsil edilememesi veya tahsil edilemeyeceğinin anlaşılması gerekmektedir. Bunun tespiti için; şirketin haczedilen mal varlığının AATUHK'ya göre belirlenen değerinin kamu alacağını karşılamaması ya da söz konusu malvarlığının satışının yapılmış olmasına rağmen kamu alacağının tamamının tahsil edilememesi, şirketin haczedilebilir nitelikte herhangi bir değerinin bulunmaması, şirketin iflasının istenmiş ya da iflasının açılmış olması durumlarında kamu alacağının iflas yoluyla tahsil edilemeyeceği kanaatinin oluşması, yapılan araştırmalara rağmen borçlu şirketin bulunamamış olması ve bu durumlara benzer olup, alacaklı tahsil dairesinin takdir ve tespitine dayalı diğer hallerden birinin veya birkaçının bulunması yeterlidir (Günay, 2012). Bu şekilde bir hükümle kamu alacağının şirketten tahsil olanağının belirlenmesi alacaklı tahsil dairesinin takdir ve tespitine bırakılmıştır. Bu düzenlemenin nedeninin kamu alacaklarının tahsiline hız kazandırmak olduğu tabiidir, fakat bu durumu belgelendirecek olan aciz vesikası aranmadan ortaklara başvurma hakkının tanınması, hem uygulamada birliği bozucu sonuçlar doğurabilecek hem de alacaklı kamu idaresinin yapmış olduğu takibin yeterli olduğu konusunda tereddüte düşürücü rol oynayacaktır (Arslaner, 2010: 80).

Limited şirketin ortaklarının sorumluluklarına esas alınan kamu alacaklarının doğduğu zamanlar, dönemleri ve ödeme zamanları kriterleri, yargı kararlarının bir kısmında benimsenmiş, ancak bu zamanlarda farklı şahısların ortak olması halinde sorumlu tayini hakkında verilen kararlar içinde görüş birliğine varılamamıştır. (Tombaloğlu, 2011: 63). Bunun yanı sıra kamu alacağının tahsil edilememesi veya tahsil edilemeyeceğinin anlaşılması aşamasından sonra takip işlemlerinin nasıl yapılacağı konusunda idare ile Danıştay arasında görüş ayrılıkları mevcuttur (Atik, 2012: 193).

\subsection{Kanuni Temsilcilerin Sorumluluğu}

Vergi kanunları bakımından kanuni temsilci, mükellef ve vergi sorumlularının vergi ile ilgili ödevlerinin zamanında ve eksiksiz yerine getirilmesi konusunda vergi kanunlarıyla yükümlü kılınan kişidir (Candan, 2007: 8). Mali hukukta kanuni temsilciye yer verilmesinin en önemli nedeni, fiil ehliyetine sahip olmayanların da vergi mükellefi veya vergi sorumlusu olabilmeleri ve bu kişilerin kamu alacaklarına ilişkin kanuni ödevlerinin zamanında ve tam olarak yerine getirilebilmesi için kanuni temsilcilere ihtiyaç duyulmasıdır (Çelik, 2000: 8). Kanuni temsilcilerin sorumluluğuna hem VUK'ta hem de AATUHK'da yer verilmiştir. VUK'un 10. maddesinde düzenlenen kanuni temsilcilerin sorumluluğu hükümleri şu şekildedir: "Tüzel kişilerle küçüklerin ve kısıtlıların, vakıflar ve cemaatler gibi tüzelkişiliği olmayan teşekküllerin mükellef veya vergi sorumlusu olmaları halinde bunlara düşen ödevler kanuni temsilcileri, tüzel kişiliği olmayan teşekkülleri idare edenler ve varsa bunların temsilcileri tarafından yerine getirilir. Belirtilen kişilerin bu ödevleri yerine getirmemeleri yüzünden mükelleflerin veya vergi sorumlularının 
varlığından tamamen veya kısmen alınamayan vergi ve buna bağlı alacaklar, kanuni ödevleri yerine getirmeyenlerin varlıklarından alınır. Bu hüküm Türkiye'de bulunmayan mükelleflerin Türkiye'deki temsilcileri hakkında da uygulanır. Temsilciler veya teşekkülü idare edenler bu suretle ödedikleri vergiler için asıl mükelleflere rücu edebilirler. Tüzel kişilerin tasfiye haline girmiş veya tasfiye edilmiş olmaları, kanuni temsilcilerin tasfiyeye giriş tarihinden önceki zamanlara ait sorumluluklarını da kaldırmaz”.

Kamu alacaklarının korunma yöntemlerinden olan kanuni temsilcilerin sorumluluğu AATUHK'nın mükerrer 35. maddesinde de düzenlenmiştir. Madde hükmüne göre; tüzel kişilerle küçüklerin ve kısıtlıların, vakıflar ve cemaatler gibi tüzel kişiliği olmayan teşekküllerin mal varlığından tamamen ve kısmen tahsil edilemeyen veya tahsil edilemeyeceği anlaşılan kamu alacakları kanuni temsilcilerin ve tüzel kişiliği olmayan teşekkülü idare edenlerin şahsi malvarlıklarından bu kanun hükümlerine göre tahsil edileceği, madde hükmünün yabancı şahıs veya kurumların Türkiye'deki temsilcileri hakkında da uygulanacağı, tüzel kişilerin tasfiye haline girmiş veya tasfiye edilmiş olmaları kanuni temsilcilerin tasfiyeye giriş tarihinden önceki zamanlara ait sorumluluklarını kaldırmayacağını, temsilcilerin, teşekkülü idare edenlerin veya mümessillerin bu madde gereğince ödedikleri tutarlar için asıl kamu borçlusuna rücu edebilecekleri belirtilmiştir. Daha sonradan 5766 Sayılı Kanunla maddeye, "kamu alacağının doğduğu ve ödenmesi gerektiği zamanlarda kanuni temsilci ve teşekkülü idare edenlerin farklı şahıslar olmaları halinde bu şahıslar kamu alacağının ödenmesinden müteselsilen sorumlu tutulur", "kanuni temsilcilerin sorumluluklarına dair VUK'ta yer alan hükümler bu maddede düzenlenen sorumluluğu ortadan kaldırmaz" hükümleri eklenmiştir.

Mükerrer 35. maddenin yürürlüğe konulmasıyla, AATUHK'da, VUK kapsamına giren vergi ve vergiye bağlı alacaklar ile vergi cezaları dışında kalan kamu alacakları hakkında VUK'un 10. maddesindekine benzer bir düzenlemenin bulunmamasının, uygulamada yarattığı eksikliğin giderilmesi amaçlanmıştır (Candan, 2007: 171). VUK'un 10. maddesinde kanuni temsilcilerin, “...ödevlerin kanuni temsilciler, tüzelkişiliği olmayan teşekkülleri idare edenler ve varsa bunların temsilcileri tarafından yerine getirilmemesi yüzünden..." hükmü açısından kusurlu sorumluluğu mevcutken, mükerrer 35. maddede öngörülen sorumluluk, kanuni temsilcinin kusurundan kaynaklanan sorumluluk değildir. Ayrıca kanuni temsilcilere yüklenen bir görevin sonucu da olmayıp sırf kanuni temsilcilik sıfatından kaynaklanmaktadır. Yine VUK'un 10. maddesinde öngörülen sorumluluğa kıyasla mükerrer 35. madde ile getirilen sorumluluk daha geniş kapsamlıdır. VUK'un kapsamına girmeyen gümrük ve tekel vergi ve resimleri, fiyat fark1, kur farkı, kaynak kullanımı destekleme primi gibi kamu alacakları dahil AATUHK'nın 1. ve 2. maddelerinde yazılı kamu alacaklarının tümü girmektedir. Bu durumun doğal sonucu olarak; alacaklı kamu idarelerinin mükerrer 35. maddeyi uygulamak istemeleri; kanuni temsilcilerin de, VUK'un 10. maddesindeki koşulların gerçekleşmediğini ileri sürerek sorumluluktan kurtulmaya çalışmaları söz konusu 
olmaktadır (Sivrikaya, 2013). 3505 Sayılı Kanunla yapılan değişiklikten önce kanuni temsilcilerin sorumluluğu kasit ve ihmal unsuruna bağlı olup ispat külfeti idareye aitti. Değişiklikten sonra ispat külfeti yer değiştirmiş ve kanuni temsilci, vergi alacağının asıl borçlunun malvarlığından tahsil edilememesinin, kendine yüklenmiş vergisel ödevlerin yerine getirilmemesinden kaynaklanmadığını ispat etmek zorunda bırakılmıştır. Ancak mükerrer 35. madde kapsamında, VUK'un 10. maddesindeki gibi kanuni temsilci kusursuzluğunu ispat ederek sorumluluktan kurtulamamaktadır. Yani kanuni temsilcinin sorumluluğuna gidilebilmesi için kendisine yüklenilen ödevleri yerine getirip getirmediği; yerine getirmemiş ise, bu kusurun kendisinden kaynaklanıp kaynaklanmadığına bakılmamaktadır (Arslaner, 2010: 97-98).

\section{Sonuç}

Kamu alacaklarının sahip oldukları niteliklerden dolayı özel alacaklardan ayrı olarak takip ve tahsili gerçekleştirilmektedir. Özel alacaklar 2004 Sayılı İcra İflas Kanununa (İ̈K) göre takip edilirken, kamu alacakları 6183 Sayılı Amme Alacaklarının Tahsil Usulü Hakkında Kanunun (AATUHK) çerçevesinde takip ve tahsil edilmektedir. $\mathrm{Bu}$ kanun takip ve tahsilin yanı sıra kamu alacaklarının korunması hükümlerini de düzenlemiştir. Kamu alacağını korumak amacıyla getirilen bu düzenlemeler alacağın tahsilinin tehlikeye girmesi gibi bir durumda tahsil aşamasını geçirmeden kamu alacağını korumaya almaktadır. Ayrıca koruma hükümlerinin varlığının farkındalığı, kamu borçlusu tarafindan borcun verilen zaman zarfi içerisinde ve eksiksiz bir şekilde ödenmesini sağlamaktadır. $\mathrm{Bu}$ çalışmada kamu alacaklarının korunması yöntemlerinden önemli görülenler üzerinde durulmuş ve uygulamadaki aksaklıkları verilmiştir.

Teminat isteme müessesesi kapsamında uygulamada karşılaşılan problem teminatın istenme yetkisidir. AATUHK'nın 9.maddesinin 1. fikrasında "istenir" şeklinde belirtilen hükümde vergi inceleme elemanının teminat istemi üzerine tahsil dairesi bu istemi işleme koymalıdır. Ancak 2. fikrasında "isteyebilir" şeklinde verilen hükümde ise teminatın gerekliliği konusu tahsil dairesinin takdirine bırakılmıştır. Uygulamada bu hükümler dikkate alınmayıp teminatın istenmesi konusunda yetki sakatlığı gibi farklı durumlarla karşılaşılmaktadır. Bu sebepten madde metninin teminat istenmesine karar verme zorunluluğu ve yetki kullanımının ayrıntılı ve net olarak tekrar düzenlenmesi gereklidir. Bunun yanı sira Gelir Vergisi Kanununda gayrimenkul olarak tescil edilen markanın, AATUHK'da ve İIK'da hem ihtiyati haczi hem de kesin haczi ve satışı mümkün bulunmaktadır. Hatta İ́K'da teminat olarak bile gösterilebilen tescilli bir marka, AATUHK'nın teminat müessesesi kapsamına da alınması gerekmektedir. Yine teminat müessesesinde kamu idaresi koşulların oluştuğu takdirde aldığı teminatı özellikle ilgili borçla sınırlı olarak kullanmalıdır. Kamu borçlusunun başka borçları için teminatın idare tarafindan elde tutulması gibi bir uygulamanın yapılmaması gerekmektedir. 
İhtiyati haczin bir taraftan re'sen doğan bir uygulama olması diğer taraftan tahakkuk etmiş ya da edecek bütün kamu alacakları için uygulanabilen geniş bir sahaya sahip olması gibi özelliklerinden dolayı bu müessesenin kullanılmasında, yerinde bir araştırma yapıldıktan sonra dikkatli adımlar atılmalı, her tarhiyat için uygulanmasının önüne geçilmeli ve ihtiyati haczin uygulanmasında kamu alacaklısı ile kamu borçlusunun menfaatleri dengede tutulup göz ardı edilmemelidir. Ayrıca mükelleflerin banka hesaplarına elektronik ortamda yapılan haciz olarak adlandırılan e-haciz uygulaması, henüz kesinleşmeyen borçlar hakkında işleme koyulmayacaktır. Dolayısıyla ihtiyati haciz kararlarının kesinleşmesi sonucunda mükellefin bankada bulunan hesabına e-haciz veya banka mevduat hacizleri koyulabilecektir. Uygulamada hata üstüne hata yapilarak vergi incelemesi son bulduktan sonra ihtiyati haciz koyulmakta ve bu karar hemen uygulanmak üzere bankalarla gerekli yazışmalar yapılmaktadır. Bu konu hakkında idarenin vergi incelemeye yetkili görevlilerinin dikkatli karar vermeleri gerekmektedir. Bankalara yapılan haciz ve ihtiyati haciz tebliğlerinde yalnızca tebliğ tarihi itibariyle mevcut olan malvarlığ hedef alınabilecektir. Bunun haricinde kamu borçlusunun bankadan ileride meydana gelecek alacaklarına kesinlikle haciz veya ihtiyati haciz konulamayacaktır. Uygulamada Gelir İdaresi Başkanlığı'nın bankalara gönderilen yazılara rağmen bankalar tarafından gerçekleştirilen hatalı işlemler borçlu mükellefleri mağdur durumda bırakmaktadır. Anayasa mahkemesinin kararı ile IYUK'un 28/1. maddesinde yer alan "haciz ve ihtiyati haciz uygulamaları ile ilgili davalarda verilen kararlar hakkında bu kararların kesinleşmesinden sonra idarece işlem tesis edilir" hükmü iptal edilmiştir. Söz konusu kararın resmi gazetede yayımlandığ 1 tarihten sonra haciz veya ihtiyati haciz işlemleri ile ilgili olarak mahkemelerce verilen iptal veya yürütmeyi durdurma kararları üzerine nihai kararın kesinleşmesini beklemeksizin vergi dairelerince kararın gereklerine göre işlem tesis edilmesi gerekmekmektedir. Verilen karar yerinde olup kamu borçlularının uzun yargılama sonucu tasarruf haklarının engellenmesi ortadan kalkacaktır.

Kamu alacağının korunması yöntemlerinden birini oluşturan ihtiyati tahakkuk uygulaması, tüm kamu alacakları için uygulanmamakta, sadece VUK kapsamına giren mükellefin henüz tahakkuk etmemiş vergi, resim ve harçlardan Maliye Bakanlığınca tespit ve ilan edilenler ile bunlara ilişkin gecikme faizi ve cezalar için uygulanmaktadır. İhtiyati tahakkuk işleminin başlatılabilmesi için vergi dairesi müdürü tarafindan yazılı olarak ihtiyati tahakkuk yapılması talebi gerekmektedir. Bu konuda vergi dairesi müdürünün takdir hakkı olmamakta, sebeplerin varlığı halinde ihtiyati tahakkuk talebinde bulunulması zorunlu olmaktadır. Defterdar veya vergi dairesi başkanının bu talebi değerlendirerek yazılı kararı üzerine ihtiyati tahakkuk derhal uygulanacaktır. Takdir yetkisi burada tamamen vergi dairesi başkanına ve defterdara aittir, ancak kararı re'sen değil vergi dairesi müdürünün isteği üzerine vermektedirler. İhtiyati tahakkuk uygulamasında bir başka önemli nokta ise yapılan ihtiyati tahakkuka karşı itiraz yoludur. İhtiyati haciz işleminde yalnızca haczin sebebine itiraz edilebildiği halde, ihtiyati tahakkuka karşı açılan davada ihtiyati tahakkukun hem sebeplerine hem de miktarına karşı dava açılabilecektir. Henüz tahakkuku gerçekleşmemiş borçlar hakkında yapılan ihtiyati hacze karşı açılacak olan 
davalarda sadece ihtiyati haciz sebeplere itiraz edilse bile dava dilekçesine ihtiyati tahakkuk için de itirazda bulunulduğu belirtilmelidir.

AATUHK'nın 21.maddesinde, üçüncü şahıslar tarafından haczedilen malların paraya çevrilmesinden önce o mal üzerine kamu alacağı için de haciz koyulması konusunda satış bedelinin ne şekilde dağıtılacağına ilişkin düzenlemeler yer almakta, aynı zamanda borçlunun iflası, mirasın reddi ve terekenin resmi tasfiyeye tabi tutulması hallerinde kamu alacağının sırası belirlenmektedir. 5479 Sayılı Kanun ile 08.04.2006 tarihinden itibaren kamu alacakları ikili bir ayrıma tabi tutulmuş ve bunlardan; genel bütçeye gelir kaydedilen vergi, resim, harç ile vergi cezaları ve bunlara bağlı feri alacaklar için rehinden önce konulmuş hacizlere iştirak edilebileceği, genel bütçeye dâhil olmayan, ancak amme alacağı statüsündeki diğer alacakların ise bu öncelik hakkından yararlanamayacağı hüküm altına alınmıştır. Rehinli alacaklar bütün alacaklara göre öncelik hakkına sahiptir. Ancak gümrük resmi, bina ve arazi vergisi gibi gayrimenkulün veya eşyanın aynından (kökeninden) kaynaklanan vergiler ve kamu alacakları o eşya ve gayrimenkulün bedelinden tahsilinde rehinli alacaklardan önce tahsil edilebileceği hükme bağlanmıştır. Kamu alacağının korunması adına yapılan bu düzenlemeler bir tarafa, eğer ki kamu alacağı için alacaklı kamu idaresi ilk haczi koymuşsa bu hacze üçüncü kişiler iştirak edemeyeceklerdir. AATUHK bu madde düzenlemesini üçüncü kişilerin menfaatine değil, kamu alacaklarını korumak amacıyla getirmiştir.

Kamu alacağının tahsilini olanaksızlaştırıcı bazı tasarrufların hükümsüzleştirilmesini sağlamak amacıyla, tahsil dairesince açılan dava iptal davasıdır. İptal davası hükümleri AATUHK'nın 24. ve 31.maddeleri arasında düzenlenmiştir. Bu davanın açılmasındaki amaç kamu borçlusu tarafından yapılan tasarrufların, kamu alacağının tahsiline yetecek kadar olan payının hükümsüz kılınmasıdır. Davanın iptal nedenleri bakımından maddede belirtilen sürelerin göz önüne alınarak açılması önem arzedecektir. Dolayısıyla sürelerin hesaplanmasında dikkatli bir şekilde karar alınması alacağın tahsilinin yapılabilmesi için mutlaktır.

Limited şirketlerin kamu borçlarında ise ortaklarının sorumlulukları açısından sıkıntı yaşanmaktadır. Kanun maddesi, Limited şirket ortaklarının şirketten tamamen veya kısmen tahsil edilemeyen veya tahsil edilemeyeceği anlaşılan kamu alacağından sermaye hisseleri oranında doğrudan doğruya sorumlu olacaklarını, ortağın şirketteki payını devretmesi halinde, payı devreden ve devralan şahıslar devir öncesine ait olan kamu alacaklarının ödenmesinden, ayrıca kamu alacağının doğduğu ve ödenmesi gerektiği zamanlarda pay sahiplerinin farklı şahıslar olmaları halinde bu şahısların kamu alacağının ödenmesinden müteselsilen sorumlu tutulacaklarını düzenlemiştir. Maddede bahsi geçen kamu alacağının doğduğu ve ödenmesi gerektiği zamanlarda pay sahiplerinin farklı şahıslar olmaları konusunda sıkıntı yaşandığı yargı kararlarının birbiriyle uyumlu olmamasından anlaşılabilmektedir. Yine madde kapsamında Limited şirketlerden kamu alacaklarının tamamen veya kısmen tahsil edilememesi ve edilemeyeceğinin 
anlaşılmasının akabinde takip işlemlerinin ne şekilde yapılması gerektiği konusunda idare ile yargı arasında görüş ayrılıkları mevcut olup kesin bir uygulama belirlenmemiştir. $\mathrm{Bu}$ konuda yargı kararları içtihatları oluşturularak bir düzenlemeye gidilmesi gerekmektedir. Limited şirket hakkında kamu alacağının tahsili için tüm cebren takip yollarının uygulanıp, kamu alacağının şirketten tamamen veya kısmen tahsil edilememesi veya tahsil edilemeyeceğinin anlaşılması durumunun tespitinin alacaklı tahsil dairesinin takdirine bırakılması, daireyi gereğinden fazla bir şekilde yetkili kılmaktadır. Limited şirketlerde yapılan takipte tahsilin mümkün olmadığını gösterir belge olan aciz vesikasının aranmadan kamu alacağı için ortaklara başvuru hakkının tanınması, uygulamada eşitliği bozucu bir işlem olmakla beraber takibin yetersizliğini gündeme getirecektir. Bu özel durumun uygulamada birliğin bozulmaması adına kaldırılması, aciz belgesinin Limited şirketlerde de aranması gerekmektedir.

Kanuni temsilcilerin sorumluluğu müessesesi vergi sistemimizde hem VUK'ta hem de AATUHK'da düzenlenmiştir. Kanuni temsilci müessesesi için VUK'un 10. maddesinde öngörülen sorumluluğa kıyasla AATUHK'nın mükerrer 35.maddesi ile getirilen sorumluluk daha geniş kapsamlıdır. VUK'a göre kanuni temsilcilerin sorumluluğunda kusurluluk durumu söz konusu iken AATUHK'da yer alan sorumluluk kusura dayandırılmamıştır. Bunların yanı sıra bu iki madde temsilciliğin süresi bakımından da farklı hükümler taşımaktadırlar. Sorumluluğun sahası bakımından menfaat doğrultusunda sorumluluk gerektirecek bir durumda alacaklı kamu idaresi mükerrer 35.maddeyi uygulamaktan yana olmakta, kanuni temsilciler ise sorumluluktan kurtulmaya çalışıp VUK'un 10. maddesindeki şartların gerçekleşmediğini savunmaktadır. Yargının bu konudaki görüşü alacaklı kamu idaresinin görüşüyle bağdaşmamakta ve vergi ve buna bağlı alacaklarda mükerrer 35 inci maddenin uygulanma olanağının bulunmadığını belirtmektedir. Konunun açıklığa kavuşması için kanuni dayanağı olan bir düzenleme yapılması gerekmektedir.

AATUHK'nın kamu alacaklarının korunmasında tahsilatın etkinliği için maddelerde düzenlemelere gidilmeli, daha da önemlisi var olan bu maddelerin uygulanmasında ticari ve ekonomik hayatın akışına uygun davranılması gerekmektedir. Ayrıca kanun maddeleri lafzı itibariyle kanunun asıl amaçladığının aksine bambaşka şekillerde yoruma tabi tutulabilmektedir. Farklı yorumlar ise uygulamada güçlüklerle karşılanmasını kaçınılmaz kılmaktadır. Dolayısıyla maddelerin belirsizliğe yer vermeden net bir şekilde hazırlanması kamu alacaklısını ve kamu borçlusunu kavram kargaşasından kurtaracaktır. 


\section{Kaynakça}

Alptürk, Ercan (2008), "Hukuksal ve Vergisel Boyutlarıyla Elektronik Haciz Uygulaması", eYaklaşım Dergisi, 60, <http://uye.yaklasim.com/MagazinDetail.aspx?magazinid=187>, 12.07.2013.

Arslaner, Hakan (2010), 6183 Sayılı Kanun Kapsamında Kamu Alacaklarının Haciz Yolu İle Tahsili, Yetkin Basımevi, Ankara.

Atik, Caner (2012), "Limited Şirketlerin Kanuni Temsilcileri ve Ortaklarının Vergi Borçları Karşısındaki Sorumlulukları”, Vergi Dünyası Dergisi, 372, s. 193.

Ay, Hakan \& Mustafa Alpaslan (2011), "Kamu Alacaklarının Takibinde Rüçhan Hakkı Uygulaması”, Legal Mali Hukuk Dergisi, 84, s. 2924.

Ay, Hakan \& Mustafa Alpaslan \& Eda Kaya (2011), Vergi Uygulamalarında e-Tebligat ve e-Haciz, Kanyılmaz Matbaası, İzmir.

Ay, Hakan \& Mustafa Alpaslan (2011), "Kamu Alacaklarının Takibinde Yeni Tip Ödeme Emrine Karşı Vergi Davası Açılması ve Yürütmenin Durdurulması Problemleri”, Vergi Dünyası Dergisi, 360, s. 165.

Aygün, Fethi (2010), “Amme Alacağının Korunmasında İhtiyati Haciz”, Lebib Yalkın Mevzuat Dergisi, 84, s. 226.

Barlas, İrfan (2011), “6183 Sayılı Amme Alacaklarının Tahsil Usulü Hakkında Kanun’un 12. maddesine Göre Teminat Hükmünde Olan Eşya”, Vergi Dünyası Dergisi, 359, s. 153.

Batun, Mehmet (2010), "Kamu Alacağının Güvence Altına Alınmasında İhtiyati Tahakkuk”, Vergi Dünyası Dergisi, 341, s. 91.

Baysal, Eda (2009), "Vergi Hukuku Yönünden Amme Alacağının Korunmasına Dair Güvence Önlemlerinden Olan Teminat İsteme Uygulamasında Yetki ve Neden Unsurlarının Tahlili”, Legal Mali Hukuk Dergisi, 54, s. 1167.

Candan, Turgut (2006), Kanuni Temsilcinin Vergi ve Diğer Kamu Alacaklarından Sorumluluğu, Maliye ve Hukuk Yayınları, Ankara.

Candan, Turgut (2007), Amme Alacaklarının Tahsil Usulü Hakkında Kanun, Maliye ve Hukuk Yayınları, Ankara.

Arslan, Cem Barlas (2010), “İhtiyati Tahakkuk Uygulaması, İtiraz ve Sonuçları”, Yaklaşım, 215.

Çelik, Binnur (2000), Kamu Alacaklarının Takip ve Tahsil Hukuku, İmaj Yayınevi, Ankara.

Dönmez, Recai (2007), "Vergi İcrası”, Fethi Heper ve Recai Dönmez (der), Vergi Hukuku, Anadolu Üniversitesi Yayınları No: 1536, Eskişehir, s. 240.

Dönmez, Recai (1998), Vergi İcra Hukukunda İhtiyati Haciz, Anadolu Üniversitesi Basımevi, Eskişehir.

Gelir İdaresi Başkanlığı (2007), 440 seri no'lu Tahsilât Genel Tebliği, $<$ http://www.gib.gov.tr/index.php?id=1028>, 12.06.2013. 
Gerçek, Adnan (2006), Türk Vergi Hukukunda İdarenin Takdir Yetkisi, Yaklaşım Yayıncılık, Ankara.

Gerçek, Adnan (2010), Kamu Alacaklarının Takip ve Tahsil Hukuku, Ekin Yayınevi, Bursa.

Günay, İbrahim Necati (2012), Limited Şirketlerde Vergi Borçlarından Sorumluluk, $<$ htp://www.muhasip.com/index.php?option=com_content\&view $=$ article\&id=216:limite d-irketlerde-vergi-borclarndan-sorumluluk\&catid=50:-hukuku\&Itemid=57>, 10.06.2013.

Günday, Metin (2005), İdare Hukuku, Anadolu Üniversitesi Yayınları No: 1467, Eskişehir.

İstanbul Vergi Dairesi Başkanlığı Mükellef Hizmetleri Tahsilât Grup Müdürlüğü (2006), 6183 Sayılı Amme Alacaklarının Tahsil Usulü Hakkında Kanun, Arıkan Yayınevi, İstanbul.

İstanbul Vergi Dairesi Başkanlığı, Mükellef Hizmetleri Tahsilât Grup Müdürlüğü, (2008) İhtiyati Tahakkuk ve Ihtiyati Haciz UygulamaRehberi, $<$ http://www.ivdb.gov.tr/internetotomasyon/yayin/TahsilatTamim.Makale/TihtiyatiT\%20uygulama\%20rehberi.doc>, 25.05.2013.

Karakoç, Yusuf (2001), “Kamu Alacaklarının Tahsili: Kamu İcra Hukuku”, Vergi Sorunları Dergisi, 153 , s. 121.

Kızılot, Şükrü \& Doğan Şenyüz \& Metin Taş \& Recai Dönmez (2007), Vergi Hukuku, 2. Bask1, Yaklaşım Yayıncılık, Ankara.

Kızılot, Şükrü (2010), "Vergi İncelemesi Bittikten Sonra Teminat ve Haciz Uygulanamayacağı", Yaklaşım, 207, s.15.

Mutluer, M. Kamil (2006), Vergi Genel Hukuku, İstanbul Bilgi Üniversitesi Yayınları No: 121, İstanbul.

Netek, Okan (2012), “Amme Alacağının Korunmasında Bir Yöntem: İhtiyati Haciz”, Yaklaşım, 230, s. 62,129 .

Öncel, Mualla \& Ahmet Kumrulu \& Nami Çağan (2010), Vergi Hukuku, Turhan Kitabevi, Ankara.

Özbalcı, Yılmaz (2012), Amme Alacaklarının Tahsil Usulü Hakkında Kanun, Oluş Yayıncılık, Ankara.

Serim, Nilgün (2007), 6183 Sayılı Kanunda Amme Alacaklarının Korunması, Türkmen Kitabevi, İstanbul.

Serim, Nilgün (2008), “Marka ve İsim Hakkı Haczi”, e-Yaklaşım Dergisi, 181, ss. 559-561.

Serim, Nilgün (2010), “Amme Alacaklarının Tahsil Usulü Hakkında Kanunda İptal Davasına Konu Tasarrufların Türleri ve Tasarrufların Hükümsüzlüğünün Hukuki Niteliği”, Vergi Sorunlart Dergisi, 266, ss. 53-54.

Sivrikaya, Hamza, Vergi ve Buna Bağll Alacakların Tahsilinde ve Ceza Kesilmesinde Kanuni Temsilcilerin Sorumluluğu, <http: //www.bilgilidenetim.com/vergi-ve-buna-baglialacaklarin-tahsilinde-ve-ceza-kesilmesinde-kanuni-temsilcilerin-sorumlulugu-2.html $>$, 13.06.2013. 
Tombaloğlu, Mustafa Lütfi (2011), Amme Alacaklarının Takip ve Tahsil Usulü, Seçkin Yayıncılık, Ankara.

Yerlikaya, Gökhan Kürşat (2011), “Türk Vergi İcra Hukukunda İhtiyati Hacze ve İhtiyati Haczin Sebebine İtiraz”, Kazancı Hukuk Dergisi, 73-74, s. 11.

Yerlikaya, Gökhan Kürşat \& Emin Barlas (2007), “İhtiyati Tahakkuka Dava Açılması”, Kazancı Hukuk Dergisi, 33-34, s. 160. 